\title{
IBUPROFEN AND ITS DIFFERENT ANALYTICAL AND MANUFACTURING METHODS: A REVIEW
}

\author{
SAGAR BASHYAL* \\ Department of Biotechnology, IILM College of Engineering and Technology, Greater Noida, Uttar Pradesh, India. \\ Email: sagar.bashyal.bt18@iilmcet.ac.in
}

Received: 29 December 2017, Revised and Accepted: 09 April 2018

\section{ABSTRACT}

Ibuprofen is a nonsteroidal anti-inflammatory drug, and many of its similar class includes aspirin, indomethacin (Indocin), naproxen (Aleve), nabumetone (Relafen), and many others. This drug is used in moderate pain, fever, and inflammation, which is promoted by the release in the body of chemicals called prostaglandins. According to the IUPAC, it is (RS)-2-(4-(2-methylpropyl)phenyl)propanoic acid. The original synthesis of ibuprofen by the Boots Group started with the compound 2-methylpropyl benzene. Ibuprofen blocks the enzyme that makes prostaglandins (cyclooxygenase), resulting in lower levels of prostaglandins that help in reducing inflammation, pain, and fever. This review is focused on various chemical and functional properties and experimental studies of ibuprofen including various detection methods such as potentiometric, ultraviolet spectrophotometric, gas chromatography, high-performance liquid chromatography (HPLC), and reverse-HPLC which can also be used for the extraction, quantification, and quality analysis.

Keywords: Ibuprofen, Anti-inflammatory, Prostaglandins, Analytical methods

(C) 2018 The Authors. Published by Innovare Academic Sciences Pvt Ltd. This is an open access article under the CC BY license (http://creativecommons. org/licenses/by/4. 0/) DOI: http://dx.doi.org/10.22159/ajpcr.2018.v11i7.24484

\section{INTRODUCTION}

Ibuprofen is a medication in the nonsteroidal anti-inflammatory drug (NSAID) class which is used for treating pain, fever, etc. [1]. It is used for the treatment of mild-to-moderate pain, inflammation, and fever caused by many and diverse diseases. It is used for treating menstrual cramps (dysmenorrhea), osteoarthritis, rheumatoid arthritis, and juvenile idiopathic arthritis. Besides its upsides, there are some downsides of ibuprofen. It increases the risk of heart, kidney, and liver failure. At low dosage, it does not appear to increase the risk of heart attack; however, at higher dosage, the risk may get an increase. This chemical drug is listed on the World Health Organization's List of Essential Medicines, the most effective and safe medicines needed in a health system.

Structural formula [2]

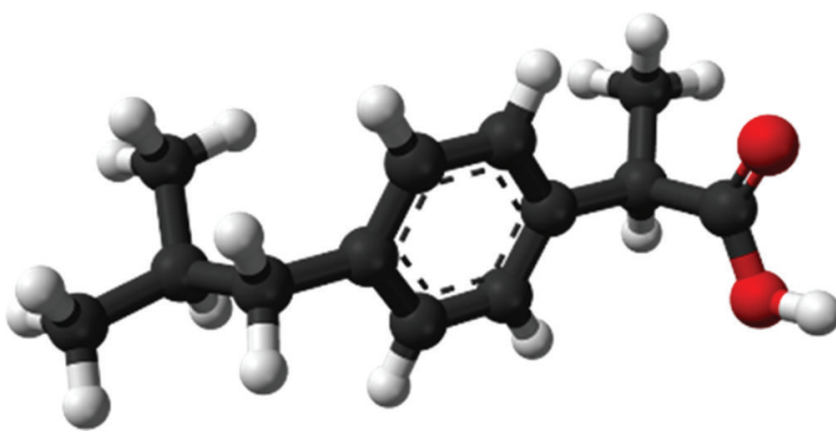

Molecular Formula: $\mathrm{C}_{13} \mathrm{H}_{18} \mathrm{O}_{2}$

Molecular Weight: $206.29 \mathrm{~g} / \mathrm{mole}$

IUPAC name: (RS)-2-(4-(2-methylpropyl)phenyl)propanoic acid

Density: $1.03 \mathrm{~g} / \mathrm{ml} \mathrm{g} / \mathrm{cm}^{3}$

Melting Point: $75-78^{\circ} \mathrm{C}\left(167-172^{\circ} \mathrm{F}\right)$

Boiling Point: $157^{\circ} \mathrm{C}\left(315^{\circ} \mathrm{F}\right)$

Odor: Characteristic odor

Color: Colorless, crystalline stable solid

\section{Synonyms}

1. Alpha-methyl-4-(2-methylpropyl)benzeneacetic acid

2. Aluminum Salt Ibuprofen
3. Brufen

4. Calcium Salt Ibuprofen

5. I.V. Solution, Ibuprofen

6. Ibumetin

7. Ibuprofen

8. Ibuprofen I.V. Solution

9. Ibuprofen Zinc

10. Ibuprofen, (+-)-Isomer

11. Ibuprofen, (R)-Isomer

12. Ibuprofen, (S)-Isomer

13. Ibuprofen, Aluminum Salt

14. Ibuprofen, Calcium Salt

15. Ibuprofen, Copper (2+) Salt

16. Ibuprofen, Magnesium Salt

17. Ibuprofen, Potassium Salt

18. Ibuprofen, Sodium Salt

19. Ibuprofen, Zinc Salt

20. Ibuprofen-Zinc

21. IP 82

22. IP-82

23. IP82

24. Magnesium Salt Ibuprofen

25. Motrin

26. Nuprin

27. Potassium Salt Ibuprofen

28. Rufen

29. Salprofen

30. Salt Ibuprofen, Magnesium

31. Salt Ibuprofen, Sodium

32. Salt Ibuprofen, Zinc

33. Sodium Salt Ibuprofen

34. Trauma Dolgit Gel

35. Trauma-Dolgit Gel

36. TraumaDolgit Gel

37. Zinc Salt Ibuprofen.

\section{Solubility}

- $\quad$ Readily soluble in most organic solvents [3].

- Very soluble in alcohol [4].

- $21 \mathrm{mg} / \mathrm{L}\left(\right.$ at $25^{\circ} \mathrm{C}$ ) [5]. 
Vapor Pressure

- $4.74 \times 10-5 \mathrm{~mm} \mathrm{Hg} @ 25^{\circ} \mathrm{C}[6]$.

\section{Pharmacology}

Ibuprofen has the analgesic and antipyretic properties. Pharmacologically, it has similar action to those of other prototypical NSAIDs. Ibuprofen is a propionic acid derived and NSAID with antiinflammatory, analgesic, and antipyretic effects and also has the cardioprotective effect of aspirin [7].

Ibuprofen having propionic acid derivatives [8] inhibits the activity of cyclooxygenase I and II that decrease the formation of precursors of prostaglandins and thromboxanes. This leads to decreased prostaglandin synthesis, by prostaglandin synthase, the main physiologic effect of the drug. Ibuprofen also causes a decrease in the formation of thromboxane A2 synthesis, by thromboxane synthase, thereby inhibiting platelet aggregation.

The absorption of the drug is rapid and complete when given orally. Ibuprofen is eliminated following biotransformation to glucuronide conjugate metabolites that are excreted in urine, with little of the drug being eliminated unchanged [9]. The excretion of conjugates may be tied to renal function, and the accumulation of conjugates occurs in end-stage renal disease. Hepatic disease and cystic fibrosis can alter the disposition kinetics of the drug. Ibuprofen is not excreted in substantial concentrations in breast milk. Significant drug interactions have been demonstrated for aspirin (acetylsalicylic acid), cholestyramine, and methotrexate.

\section{Mechanism of action}

Cyclooxygenase (COX), which is required for the synthesis of prostaglandins through the arachidonic acid pathway, converts the arachidonic acid to prostaglandin $\mathrm{H} 2$ in the body. Anticoagulant effects are also mediated through inhibition of COX, which converts arachidonic acid into thromboxane $\mathrm{A} 2$, a vital component in platelet aggregation that leads to the formation of blood clots. Thus, The excess amount of NSAID may cause the long-term blockage of the COX-1 which is a subtype of COX that may cause gastric toxicity because the maintenance of the gastric mucosa is disturbed.

\section{Uses}

Ibuprofen is used primarily for,

- Headache.

- Back pain

- Menstruation pain

- Pain in teeth.

- Symptoms of cold and influenza.

- Pain in body.

- Analgesic.

- Muscle pain.

- Joint pain

- Pain in nerves.

\section{Contraindications}

Hypersensitivity to ibuprofen is a contraindication. In addition, ibuprofen should not be used in the following conditions.

- Active peptic ulcer.

- Aspirin.

- Breastfeeding.

- Gastrointestinal bleeding

- Hypersensitivity.

- Neonates with congenital heart disease.

- A study of pregnant women suggests that those taking any type or amount of NSAIDs (including ibuprofen, diclofenac, and naproxen) were 2.4 times more likely to miscarry than those not taking the drugs [10].

\section{SIDE EFFECTS}

- Abdominal pain [11].
- $\quad$ Allergic reactions [12]

- Kidney problems [13].

- Hepatic problems.

- Abnormal blood counts.

- Severe skin reactions.

- Feeling sick.

- Loose motions.

- High blood pressure.

- Skin rash.

- Liver problems [14].

- Itching

- Bleeding from the skin or nose

- Severe skin allergies [15].

- Heartburn [16].

- Constipation

- Gas.

- Headache

\section{Safety methods}

- Consult with a doctor before taking ibuprofen.

- Avoid taking an alcohol or salicylates to prevent bleeding.

- Consult your doctor if you develop blurred vision, ringing, or roaring in the ears.

- Consult your doctor if you have systemic lupus erythematosus.

- Inform your doctor if you have bruising or bleeding.

- Take the drug with a meal or snack to prevent upset stomach.

- Keep away from heat, hot surface, sparks, open flames and other ignition sources - no smoking.

\section{Dosage}

Ibuprofen can be found in various forms such as tablets and inhalation. The various dosages according to the type of diseases and age of a person can be as follows.

- People of age between 20 to 45 years suffering from fever and minor aches are treated with 200-400 mg for every 4-6 hours.

- A person with arthritis is treated with 300-800 mg 3 or 4 times daily.

- Individuals should not use ibuprofen for more than 10 days for the treatment of pain or more than 3 days for the treatment of a fever unless directed by a physician.

- Children from 6 months to 12 years of age usually are given $5-10 \mathrm{mg} / \mathrm{kg}$ of ibuprofen every $6-8 \mathrm{~h}$ for the treatment of fever and pain. The maximum dose is $40 \mathrm{mg} / \mathrm{kg}$ daily.

- A person suffering from juvenile arthritis is treated with 20-40 mg/kg/day in 3-4 divided doses.

\section{Studies and specifications}

Many studies have revealed different cases of the ibuprofen effect on various human cells as well as other living microbes and also other components showing similar activity to ibuprofen. Beauchamp et al. found oil from the olive plant showing similar ibuprofen activity due to the presence of oleocanthal [17]. Studies showed that inflammation and plaque pathology is suppressed by ibuprofen in mouse for Alzheimer disease [18]. In 1993, Hasson et al. were able to study the ibuprofen effect on the muscle soreness, damage, and performance where they found that prophylactic damage of ibuprofen does not prevent creatine kinase release from the muscle but decrease the soreness of muscle and help in restoring the muscle function for certain period of time [19]. Similarly, in 2002, Trappe et al. also studied the effect of two analgesics ibuprofen (IBU: 1,200 mg/day) and acetaminophen (ACET: $4,000 \mathrm{mg} /$ day) on muscle protein and soreness. They found an active influence of ibuprofen in the muscle protein [20]. With the advancement in research, in 2004, Schnitzer et al. were able to study and compare lumiracoxib with ibuprofen. They found that lumiracoxib was able to decrease the ulcer complication by two to three folds than the NSAID [21]. Bernard et al. studied the effect of ibuprofen on the physiology and survival of patients with Sepsis where they concluded that ibuprofen helps in reducing levels of prostacyclin and thromboxane with a decrease in consumption, tachycardia, fever, oxygen, and lactic acidosis but does not prevent the development of shock or the acute respiratory 
distress syndrome [22]. Studies also reveal that ibuprofen possess the antifungal activities [23].

Each drug after a design requires the clinical trial process where several types of animals are used. After successful trials on animals, human trials are performed. Some of the animals trialed during the testing of ibuprofen and their effects toward the given drug are given in Table 1.

\section{Trade names}

Ibuprofen is available in different trade name by different companies as shown in Table 2 .

\section{METHODS OF MANUFACTURING}

Various methods can be employed to manufacture the ibuprofen and its common constituents Table 3. Industrially, ibuprofen can be produced by biological transformation process, but due to some costlier process, easy methods are being used where chemical synthesis process is the most prominent one.

\section{ANALYTICAL METHODS}

Several drugs need to be isolated and identified from the impurity source that helps to give in rise to the derivate of several other drugs. These stages were as follows [30-32]

- Sample set selection.

- Chromatographic conditions and phases, typically using solvent strength model.

- Optimization.
Various analytical methods can be used to determine ibuprofen. The methods are as follows:

\section{Potentiometry}

Potentiometry is a technique based on a measurement of the potential difference between an indicator electrode and a reference electrode in solution, while the current is held at zero [33].

For the potentiometric determination of ibuprofen, sodium hydroxide and triethanolamine can be used as titrants.

The influence of different solvents, such as water, methanol, acetonitrile, dimethyl sulfoxide, and $\mathrm{N}, \mathrm{N}$-dimethylformamide, on the conductometric titrations can be investigated.

The same titrants as in the potentiometric titrations can be used.

The methods are accurate, and the results are reproducible in quantities ranging from 1 to $10 \mathrm{mg}$ of ibuprofen in analyzed pharmaceutical dosage forms

\section{Chromatographic and ultraviolet (UV) spectrophotometric methods}

In early ages, most of the analytical methods were done using thin-layer spectrophotometric, differential pulse polygraph, colorimetric [34], gas-liquid chromatography [35-38], paper chromatography, or direct liquid introduction mass spectrometry (MS). However, due to greater facilitate sample preparation, those early methods have largely been

Table 1: Experimental studies of ibuprofen

\begin{tabular}{|c|c|c|c|}
\hline Organism & Route & Reported dose & Effect \\
\hline Holstein's calves & Intraperitoneal & $10 \mathrm{mg} / \mathrm{kg}$ & $\begin{array}{l}\text { Ibuprofen decreased PGE2, modulated the immune response, lung } \\
\text { histopathology was not affected, and viral shedding was increased [24] }\end{array}$ \\
\hline Rat & Intravenous & $20 \mathrm{mg} / \mathrm{kg}$ body wt./day & $\begin{array}{l}\text { Rats injected with ibuprofen significantly worsened compared to } \\
\text { non-treated injured animals [25] }\end{array}$ \\
\hline Sprague-Dawley rats & Oral & $15 \mathrm{mg} / \mathrm{kg}$ & $\begin{array}{l}\text { Fracture histology and serum osteocalcin levels were no different in } \\
\text { treated animals than control animals [26] }\end{array}$ \\
\hline Infants & Oral & $2.2 \mathrm{mg} / \mathrm{kg} /$ day & $\begin{array}{l}\text { Prophylactic ibuprofen reduces the need for surgical ligation of patent } \\
\text { ductus arteriosus but does not reduce mortality or morbidity [27] }\end{array}$ \\
\hline
\end{tabular}

Table 2: Trade name and respective companies of Ibuprofen

\begin{tabular}{lll}
\hline Brand Name & Dosage Forms & Company \\
\hline Motrin & Tablets, Suspension & Sigma-Aldrich \\
Brufen & Tablets & Wyeth Pharmaceuticals Inc. \\
Nurofen & Tablets & Reckitt Benckiser Pharmaceuticals \\
Advil & Tablets & Pfizer \\
Dolgit & Tablets & Dolorgiet, Budapharma \\
Lipton & Tablets & Wyeth Pharmaceuticals Inc. \\
Anflagen & Tablets & Adare pharmaceuticals Inc. \\
Apsifen & Tablets & TEVA UK Limited \\
Trendar & Tablets & Zibo Xinhua-Perrigo Pharmaceutical Co., Ltd. \\
Buburone & Tablets & BCM \\
\hline
\end{tabular}

Table 3: Chemical and processes for ibuprofen manufacturing

\begin{tabular}{lll}
\hline S.No. & Chemicals & Process \\
\hline 1. & $\begin{array}{l}\text { Isobutyl benzene+acetyl } \\
\text { chloride+triethylaluminum+potassium cyanide. } \\
\text { isobutyl benzene+propionyl chloride+methanol. }\end{array}$ & $\begin{array}{l}\text { Friedel-Crafts acylation/cyanohydrin formation/hydrogenation/nitrile } \\
\text { hydrolysis [28] } \\
\text { Friedel-Crafts acylation/ketal formation/alpha bromination/ } \\
\text { rearrangement [28] }\end{array}$ \\
3. & $\begin{array}{l}\text { Isobutyl benzene+acetyl chloride+carbon monoxide. } \\
\text { Isobutyl benzene+acetyl chloride+methyl chloroacetate. }\end{array}$ & $\begin{array}{l}\text { Friedel-Crafts acylation/carbonyl reduction/carbonylation[28] } \\
\text { Friedel-Crafts acylation/Darzens reaction/hydrolysis/decarboxylation/ } \\
\text { carbonyl oxidation [28] } \\
\text { Methylation, saponification, Decarboxylation [29] }\end{array}$ \\
\hline
\end{tabular}


Table 4: Chromatographic and UV spectrophotometric methods for various experiments

\begin{tabular}{|c|c|c|c|c|c|}
\hline S. No. & Title & Method & Mobile phase & Column & Wavelength (nm) \\
\hline 1 & $\begin{array}{l}\text { Ethambutol hydrogen } \\
\text { chloride and ibuprofen } \\
\text { determination in tablets [41] }\end{array}$ & $\begin{array}{l}\text { Reversed-phase } \\
\text { HPLC }\end{array}$ & Methanol-H2O (70:30) & $\begin{array}{l}\text { Bonda Pak } \\
\text { C18 column } \\
\text { packed with } \\
\text { octadecylsilane } \\
\text { bonded to porous } \\
\text { silica }\end{array}$ & 254 \\
\hline 2 & $\begin{array}{l}\text { Ibuprofen in acidified plasma } \\
\text { extraction application to a C2 } \\
\text { extraction cartridge [42] }\end{array}$ & HPLC & $\begin{array}{l}55 \% \text { acetonitrile/ } 45 \% 0.02 \mathrm{H} \\
\text { phosphate buffer; pH } 3.0\end{array}$ & $\begin{array}{l}\text { Nucleosil C18 } \\
\text { column }\end{array}$ & 300 \\
\hline 3 & NSAIDs in plasma [43] & HPLC & $\begin{array}{l}\text { Phosphoric acid } \\
0.03 \%(\mathrm{pH} 2.5) \text {-acetonitriles }\end{array}$ & Silica column & $229-313$ \\
\hline 4 & $\begin{array}{l}\text { Chromatographic and } \\
\text { electrochemical methods } \\
\text { for biological material } \\
\text { analyses [44] }\end{array}$ & $\begin{array}{l}\text { Capillary } \\
\text { column gas } \\
\text { chromatography }\end{array}$ & $\begin{array}{l}500 \mathrm{mg} \text { lithium perchlorate } \\
\text { trihydrate, } 110 \mathrm{ml} \text { water, and } \\
\text { methanol up to } 1 \mathrm{l} \text {. }\end{array}$ & $\begin{array}{l}\text { Hypersil APS } \\
\text { column }\end{array}$ & 219 \\
\hline 6 & $\begin{array}{l}\text { Screening of plasma samples } \\
\text { for the presence of sixteen } \\
\text { NSAIDs [46] }\end{array}$ & Isocratic HPLC & $\begin{array}{l}\text { Acetonitrile - } 0.3 \% \text { Acetic } \\
\text { Acid - Tetrahydrofuran (36:63.1:0.9, } \\
\text { vol/vol) }\end{array}$ & $\begin{array}{l}\text { Octadecyl } \\
\text { Reversed-phase } \\
\text { column }\end{array}$ & 254 and 370 \\
\hline 7 & $\begin{array}{l}\text { Ibuprofen determination in } \\
\text { plasma [47] }\end{array}$ & HPLC & 0.05\% Isopropyl alcohol in heptane & $\begin{array}{l}\text { Two silica } \\
\text { columns }\end{array}$ & 240 \\
\hline 8 & $\begin{array}{l}\text { Ibuprofen determination in } \\
\text { serum [48] }\end{array}$ & HPLC & $\begin{array}{l}\text { Methanol-water-glacial acetic } \\
\text { acid (pH 3.4) (75:24:1, v/v) }\end{array}$ & $\begin{array}{l}\mu \text { Bondapak C1 } \\
\text { column }\end{array}$ & 272 \\
\hline 9 & $\begin{array}{l}\text { Ibuprofen determination in } \\
\text { plasma [49] }\end{array}$ & HPLC & $\begin{array}{l}65 \% \text { Methanol and } 35 \% 0.10 \mathrm{M} \\
\text { acetate buffer (pH 5.0) }\end{array}$ & $\begin{array}{l}\text { Octadecylsilane } \\
\text { column }\end{array}$ & 253 \\
\hline 10 & $\begin{array}{l}\text { Identification of } \\
\text { anti-inflammatory drugs } \\
\text { from blood. [50] }\end{array}$ & HPLC & $\begin{array}{l}\text { Acetonitrile - acetate buffer (pH } 4.2 \\
\text { or } 4.8 \text { ) }\end{array}$ & $\begin{array}{l}\text { Hypersil } \\
\text { octadecylsilane } \\
\text { analytical column }\end{array}$ & 250 \\
\hline
\end{tabular}

HPLC: High-performance liquid chromatography, NSAIDs: Nonsteroidal anti-inflammatory drugs, UV: Ultraviolet

replaced by high-performance liquid chromatography (HPLC), gas chromatography (GC) [39], and GC-MS [40], and a recent report describes the use of HPLC Table 4.

\section{CONCLUSION}

The study revealed that ibuprofen is a popular drug popular for its medicinal features in the pharmaceutical sector that can be used for the treatment of pain, fever, and inflammation. Although there are a lot of advantages, one should use the right amount of drug with consultation by doctor. Ibuprofen has been discussed in all its aspects in this review. HPLC-UV methods were found to be the most widely used. Furthermore, the analytical mentioned are time-saving, simple and do not require elaborate treatments associated with chromatographic methods. With any no doubt, future will be gifted by newer types of ibuprofen formulation techniques.

\section{CONFLICTS OF INTEREST}

The author declares that no conflict of interest occurred during the work.

\section{REFERENCES}

1. Davies NM. Clinical pharmacokinetics of ibuprofen. The first 30 years. Clin Pharmacokinet 1998;34:101-54.

2. Shankland N, Wilson CC, Florence AJ, Cox PJ. Refinement of ibuprofen at $100 \mathrm{~K}$ by single-crystal pulsed neutron diffraction. Acta Crystallogr C 1997;53:951-4.

3. ONeil MJ. The Merck Index-An Encyclopedia of Chemicals, Drugs, and Biologicals. $13^{\text {th }}$ ed. Whitehouse Station, NJ: Merck and Co Inc.; 2001. p. 876.

4. Osol A. Remington's Pharmaceutical Sciences. $16^{\text {th }}$ ed. Easton Pennsylvania: Mack Publishing Co.; 1980. p. 1057

5. Yalkowsky SH, Dannenfelser RM. The AQUASOL Database of Aqueous Solubility. Ver 5. Tucson AZ: University AZ College of Pharmacy; 1992.
6. Daubert TE, Danner RP. Physical and Thermodynamic Properties of Pure Chemicals Data Compilation. Washington DC: Taylor and Francis; 1989.

7. MacDonald TM, Wei L. Effect of ibuprofen on cardioprotective effect of aspirin. Lancet 2003;361:573-4.

8. Peneva P. Non-steroidal anti-inflammatory drugs for topical ophthalmic administration: Contemporary trends. Int $\mathrm{J}$ Pharm Pharm Sci 2015;7:13-9.

9. Mazaleuskaya LL, Theken KN, Gong L, Thorn CF, FitzGerald GA, Altman RB, et al. PharmGKB summary: Ibuprofen pathways. Pharmacogenet Genomics 2015;25:96-106.

10. Verma P, Clark CA, Spitzer KA, Laskin CA, Ray J, Koren G, et al. Use of non-aspirin NSAIDs during pregnancy may increase the risk of spontaneous abortion. Evid Based Nurs 2012;15:76-7.

11. Rossi S. Australian Medicines Handbook. Adelaide: The Australian Medicines Handbook Unit Trust; 2013.

12. Castellsague J, Riera-Guardia N, Calingaert B, Varas-Lorenzo C, Fourrier-Reglat A, Nicotra F, et al. Individual NSAIDs and upper gastrointestinal complications: A systematic review and meta-analysis of observational studies (the SOS project). Drug Saf 2012;35:1127-46.

13. Murray MD, Brater DC. Renal toxicity of the nonsteroidal antiinflammatory drugs. Annu Rev Pharmacol Toxicol 1993;33:435-65.

14. Lee CY, Finkler A. Acute intoxication due to ibuprofen overdose. Arch Pathol Lab Med 1986;110:747-9.

15. Zhou L, Dhopeshwarkar N, Blumenthal KG, Goss F, Topaz M, Slight SP, et al. Drug allergies documented in electronic health records of a large healthcare system. Allergy 2016;71:1305-13.

16. Boardman PL, Nuki G, Hart FD. Ibuprofen in the treatment of rheumatoid arthritis and osteo-arthritis. Ann Rheum Dis 1967;26:560-1.

17. Beauchamp GK, Keast RS, Morel D, Lin J, Pika J, Han Q, et al. Phytochemistry: Ibuprofen-like activity in extra-virgin olive oil. Nature 2005;437:45-6.

18. Lim GP, Yang F, Chu T, Chen P, Beech W, Teter B, et al. Ibuprofen suppresses plaque pathology and inflammation in a mouse model for Alzheimer's disease. J Neurosci 2000;20:5709-14.

19. Hasson SM, Daniels JC, Divine JG, Niebuhr BR, Richmond S, Stein PG, et al. Effect of ibuprofen use on muscle soreness, damage, and performance: A preliminary investigation. Med Sci Sports Exerc 
1993;25:9-17.

20. Trappe TA, White F, Lambert CP, Cesar D, Hellerstein M, Evans WJ, et al. Effect of ibuprofen and acetaminophen on postexercise muscle protein synthesis. Am J Physiol Endocrinol Metab 2002;282:E551-6.

21. Schnitzer TJ, Burmester GR, Mysler E, Hochberg MC, Doherty M, Ehrsam E, et al. Comparison of lumiracoxib with naproxen and ibuprofen in the therapeutic arthritis research and gastrointestinal event trial (TARGET), reduction in ulcer complications: Randomised controlled trial. Lancet 2004;364:665-74.

22. Bernard GR, Wheeler AP, Russell JA, Schein R, Summer WR, Steinberg KP, et al. The effects of ibuprofen on the physiology and survival of patients with sepsis. The ibuprofen in sepsis study group. N Engl J Med 1997;336:912-8.

23. Narwal M, Balhara M, Chaudhary R, Chhillar A. In vitro antimycotic evaluation and preliminary combinatorial studies of ibuprofen with standard antifungal drugs against Aspergillus spp. Asian J Pharm Clin Res 2017;10:113-6.

24. Walsh P, Behrens N, Carvallo Chaigneau FR, McEligot H, Agrawal K, Newman JW, et al. A randomized placebo controlled trial of ibuprofen for respiratory syncytial virus infection in a bovine model. PLoS One 2016;11:e0152913.

25. Browne KD, Iwata A, Putt ME, Smith DH. Chronic ibuprofen administration worsens cognitive outcome following traumatic brain injury in rats. Exp Neurol 2006;201:301-7.

26. Huo MH, Troiano NW, Pelker RR, Gundberg CM, Friedlaender GE. The influence of ibuprofen on fracture repair: Biomechanical, biochemical, histologic, and histomorphometric parameters in rats. J Orthop Res 1991:9:383-90.

27. Gournay V, Roze JC, Kuster A, Daoud P, Cambonie G, Hascoet JM, et al. Prophylactic ibuprofen versus placebo in very premature infants: A randomised, double-blind, placebo-controlled trial. Lancet 2004;364:1939-44

28. Ashford RD. Ashford's Dictionary of Industrial Chemicals. London, England: Wavelength Publications Ltd.; 1994. p. 495.

29. Gerhartz W. Ullmann's Encyclopedia of Industrial Chemistry. $5^{\text {th }}$ ed. Deerfield Beach, FL: VCH Publishers; 1985. p. 41

30. Ahuja S, Scypinski S. Handbook of Modern Pharmaceutical Analysis. New York: Academic Press; 2001. p. 298

31. Ahuja S. Chiral Separations by Chromatography. New York: Oxford University Press; 1997. p. 365.

32. Ahuja S. Chromatography of Pharmaceuticals: Natural, Synthetic and Recombinant Products. Washington DC: Journal of the American Chemical Society; 1992. p. 14.

33. Ahuja S. Trace and Ultra trace Analysis by HPLC. New York: Willey; 1992. p. 84

34. Fujise H. A simple and sensitive colorimetric determination of ibuprofen from plasma and urine in dogs after dosing. Nihon Juigaku Zasshi 1977;39:671-3

35. Kaiser DG, Vangiessen GJ. GLC determination of ibuprofen
$[( \pm)$-2-(p-isobutylphenyl) propionic acid in plasma. J Pharm Sci 1974;63:219-21.

36. Hoffman DJ. Rapid GLC determination of ibuprofen in serum. J Pharm Sci 1977;66:749-50.

37. Midha KK, Cooper JK, Hubbard JW, McGilveray IJ. A rapid and simple GLC procedure for determinations of plasma concentrations of ibuprofen. Can J Pharm Sci 1977;12:29-31.

38. Kaiser DG, Martin RS. Electron-capture GLC determination of ibuprofen in serum. J Pharm Sci 1978;67:627-30.

39. Singh NN, Pasutto FM, Coutts RT, Jamali F. Gas chromatographic separation of optically active anti-inflammatory 2-arylpropionic acids using (+)- or (-)-amphetamine as derivatizing reagent. J Chromatogr 1986;378:125-35.

40. Zhao MJ, Peter C, Holtz M-C, Hugenell N, Koffel JC, Jung L. Gas chromatographic-mass spectrometric determination of ibuprofen enantiomers in human plasma using $\mathrm{R}(-)$-2,2,2-trifluoro-1-(9-anthryl) ethanol as derivatizing reagent. J Chromatogr 1994;656:441-6

41. Sen AK, Bandyopadhyay A, Podder G, Chowdhury B. Reversed-phase high-performance liquid-chromatographic determination of ibuprofen and ethambutol in pharmaceutical dosage form. J Indian Chem Soc 1990;67:443-4.

42. Karnes HT, Rajasekharaiah K, Small RE, Farthing D. Automated solid phase extraction and HPLC analysis of ibuprofen in plasma. J Liq Chromatogr 1988;11:489-9.

43. Owen SG, Roberts MS, Freisen WT. Rapid high-performance liquid chromatographic assay for the simultaneous analysis of non-steroidal anti-inflammatory drugs in plasma. J Chromatogr 1987;416:293-302.

44. Berner G, Staab R, Wagener HH. Determination of ibuprofen in plasma, synovial fluid and tissue by HPLC with electrochemical detection in the lower ng-range. Fresenius J Anal Chem 1990;336:238.

45. Omile CI, Tebett IR. Determination of ten anti-inflammatory drugs in serum by isocratic liquid chromatography. Chromatographia 1986;22:1-6

46. Lapicque F, Netter P, Bannwarth B, Trechot P, Gillet P, Lambert H, et al. Identification and simultaneous determination of non-steroidal antiinflammatory drugs using high-performance liquid chromatography. J Chromatogr B 1989;496(2):301-20.

47. Lee EJD, Williams KM, Graham GG, Day R, Champion GD. Liquid chromatographic determination and the plasma concentration profile of the optical isomers of ibuprofen in man. J Pharm Sci 1984;73:1542-4.

48. Kearns GL, Wilson JT. Determination of ibuprofen in serum by highperformance liquid chromatography and application to ibuprofen disposition. J Chromatogr 1981;226:183-90.

49. Shimek JL, Rao NG, Khalil SK. High-pressure liquid chromatographie determination of ibuprofen in plasma. J Pharm Sci 1981;70:514-6.

50. Streete PJ. Rapid high-performance liquid chromatographic methods for the determination of overdose concentrations of some non-steroidal anti-inflammatory drugs in plasma or serum. J Chromatogr 1989;495:179-93 